\title{
Estudio Transversal sobre la Relación entre Neuroticismo y Curso Clínico en Pacientes con Enfermedades Inflamatorias Intestinales
}

\section{Cross-sectional Study on the Relationship Between Neuroticism and Clinical Course in Patients with Inflammatory Bowel Disease}

\author{
Juan Carlos Fernández Méndez \\ Universidad de A coruña
}

\author{
José Andrés Pérez Vidal \\ Instituto de Psicología
}

\author{
Berta Fernández Méndez \\ Instituto de Psicología
}

\begin{abstract}
Resumen. En el presente trabajo se analiza la relación que existe entre neuroticismo y diversas condiciones médicas que hacen referencia al curso clínico de las enfermedades inflamatorias intestinales. Para desarrollar la investigación se tomaron medidas en neuroticismo mediante el Inventario de Personalidad de Eysenck a 106 participantes diagnosticados de colitis ulcerosa y enfermedad de Crohn. Los resultados reflejaron que la muestra global de pacientes con enfermedades inflamatorias intestinales mostraba valores en neuroticismo que se hallaban dentro de la normalidad; sin embargo, se pudo verificar que los valores diferían dependiendo del curso clínico de la patología. El estudio sugiere que las variaciones en neuroticismo son considerables cuando se analizan los datos de la muestra general y cuando se tienen en cuenta diversas condiciones del curso clínico.

Palabras clave: Enfermedad inflamatoria intestinal, colitis ulcerosa, enfermedad de Crohn, neuroticismo y curso clínico.
\end{abstract}

\begin{abstract}
This paper analyzes the relationship between neuroticism and various medical conditions related to the clinical course of inflammatory bowel diseases. To undertake the research, neuroticism measures were taken in 106 patients diagnosed with ulcerative colitis and Crohn's disease, using the Eysenck Personality Inventory. Results showed that the sample of patients with inflammatory bowel diseases had neuroticism values that were within normal limits; however, it was also seen that the values differed depending on the clinical course of the disease. The study suggests that variations in neuroticism are significant when considering the overall sample data and when taking into account different nature of the clinical course.

Key words: Inflammatory bowel disease, ulcerative colitis, Crohn's disease, neuroticism and clinical course.
\end{abstract}

\section{Introducción}

El presente estudio tiene como objetivo conocer la relación entre ciertas condiciones del curso clíni-

La correspondencia sobre este artículo dirigirla al primer autor: Juan Carlos Fernández, Universidad de A Coruña, Departamento de Psicología, Campus de Elviña s/n, 15071 A Coruña. E-mail: jcfernandez@udc.es co de las enfermedades inflamatorias intestinales (EII) y el neuroticismo.

Las EII son patologías que presentan una importante severidad, son crónicas y, generalmente, alternan con períodos de actividad y quiescencia, agrupando a dos entidades, la colitis ulcerosa (CU) y la enfermedad de Crohn (EC). En la CU únicamente 
está comprometido el colon, siendo el principal síntoma en período de actividad el sangrado rectal o rectorragia, mientras que en la EC se puede ver afectado cualquier segmento del tracto gastrointestinal, dependiendo la sintomatología de la distribución anatómica, la extensión de las lesiones y la presencia de complicaciones, aunque los síntomas más frecuentes son la diarrea y el dolor abdominal (Podolsky, 2002). Ambas patologías pueden aparecer en cualquier etapa del ciclo vital y presentan una distribución similar en ambos sexos (Farrokhyar, Swarbrick e Irving, 2001). La etiología de las EII es desconocida, aunque se sospecha que posiblemente sea multifactorial (factores genéticos, inmunes, vasculares, ambientales y psicológicos). Al desconocerse las causas que producen estas enfermedades el tratamiento es paliativo y con notorios efectos secundarios.

La importante repercusión de la EC y CU sobre la calidad de vida de los pacientes (Levenstein, 2004; López, Moreno, Devesa y Rodríguez, 2005) ha llevado a los investigadores a considerar la asociación entre EII y trastornos psicológicos, estrés y factores de personalidad. De acuerdo a la bibliografía, se ha encontrado una mayor prevalencia de trastornos psicológicos entre los pacientes de CU y EC que en la población general (Guthrie, Jakson, Shaffer, Thompson, Tomenson y Creed, 2002), especialmente depresión y ansiedad. Asimismo, se ha encontrado que el estrés exacerba la sintomatología gastrointestinal (Duffy, Zielezny, Marshall, Weiser, Phillips, Byers et al., 2001) y que las estrategias de afrontamiento pueden influir en una mejor o peor adaptación a las EII (Jones, Wessinger y Crowell, 2006). Finalmente, se ha verificado que estos pacientes pueden presentar puntuaciones más elevadas en diversas variables de personalidad (Tabla 1).

El neuroticismo ha sido una de las dimensiones de personalidad más estudiadas; de este modo, se sabe que las personas con elevados niveles de neuroticismo tienden a mostrar reacciones emocionales extremas y presentan mayores dificultades para recuperar el estado basal después de vivenciar una situación estresante. Además, el neuroticismo altera el bienestar psicológico (Emmons y Diener, 1985) y se relaciona con enfermedades físicas (Friedman y Booth-Kewley, 1987; Eysenck, 1991).

De la revisión bibliográfica realizada por Vidal, Gómez y Peri (2003) se desprende que el neuroticismo es una de las variables de personalidad más estudiadas en el ámbito de las EII. Se han encontrado puntuaciones superiores a la población general en la variable de personalidad neuroticismo (Gathman, Linzmayer y Grunberger, 1981), sin existir diferencias entre pacientes de CU y EC (Robertson, Ray, Diammond y Edwards, 1989; Barret, Standon, Lee y Edwards, 1996). Por otra parte, niveles elevados en neuroticismo están asociados en estos pacientes con bajos niveles de calidad de vida relacionada con salud (Moreno, López, Rodríguez y Garrosa, 2007).

Sin embargo, nos surge la duda de cómo puede influir en los resultados de dichas investigaciones la consideración del curso clínico de estas patologías, y si los resultados variarán dependiendo de si hay o no actividad clínica, síntomas extradigestivos, el tipo de medicación utilizado para reducir la inflamación del intestino, etc., debido a que la CU y la EC son patologías que muestran una evolución muy variable, sorprendentemente benigna en algunos casos y de gran virulencia en otros (Podolsky, 2002). En unos pacientes existe alternancia entre períodos de actividad y remisión, mientras que en otros los períodos de actividad son casi permanentes y conducen a un claro deterioro. También cabe señalar que son cuadros clínicos de gran heterogeneidad, encontrándose pacientes cuya manifestación de la sintomatología es únicamente digestiva, mientras que en otros pacientes muestran afectación, además del

Tabla 1. Evidencia favorable a la asociación personalidad y EII

Autores

Sheffield y Carney (1976)

Liedtke, Freyberger y Zepf (1977)

Steinhausen y Kies (1982)

Helzer, Chammas, Norland, Stillings y Alpers (1984)

Porcelli, Leoci, Guerra, Taylor, y Bagby (1996)

Tocci, Lepre, Liotta, Masón, Costa, Tabotra y Miccini (1997)
Características de personalidad

Neuroticismo

Introversión

"Locus" de control interno

Rasgos obsesivos

Alexitimia

Ansiedad rasgo 
tracto gastrointestinal, en otros órganos y sistemas (piel, ojos, riñones, etc.). Por esta razón, la elección del tratamiento médico difiere de un paciente a otro, dependiendo de factores como la severidad de la sintomatología, tipo de patología, fase de la misma y su estado general. También la repuesta a dicho tratamiento es muy diversa, resultando muy favorable en unos casos y en otros se hace evidente la refractariedad al mismo, llegando los pacientes a requerir múltiples hospitalizaciones e, incluso, distintas intervenciones quirúrgicas.

En nuestro estudio se analiza la relación entre neuroticismo y curso clínico de las EII, y partimos de la hipótesis que existirán probables diferencias en neuroticismo dependiendo de la fase de actividadinactividad de la enfermedad, presencia-ausencia de sintomatología extradigestiva y el tipo de tratamiento biomédico.

\section{Método}

\section{Participantes}

Se reclutó una muestra compuesta por 60 mujeres y 46 varones seleccionados por medio de muestreo no aleatorio, diagnosticados de EII según parámetros clínicos, radiológicos, endoscópicos y anatomopatológicos en régimen ambulatorio. De los 106 participantes, 49 padecían CU y 57 EC. En la Tabla 2 se resumen las principales características de la muestra de participantes.

\section{Instrumentos}

Cuestionario sobre las enfermedades inflamatorias intestinales

Se diseñó un protocolo para recabar información sobre determinados aspectos de las enfermedades inflamatorias crónicas intestinales. En una primera sección se recogen los principales datos socio-biográficos, mientras que en la segunda sección se recoge información sobre la historia y evolución de la enfermedad.

\section{Inventario de personalidad de Eysenck (EPI)}

El EPI (Eysenck Personality Inventory) es un cuestionario elaborado en el año 1964 por Eysenck y Eysenck a partir del Maudsley Personality Inventory, y consta de 57 ítems que conforman tres escalas para evaluar dos dimensiones de personalidad, y una escala para detectar deseabilidad social. Las dos dimensiones que mide este instrumento son, en base a un esquema ortogonal, la extraversiónintroversión (factor E) y estabilidad emocional-inestabilidad emocional (neuroticismo o factor N). En este caso, únicamente hemos considerado las puntuaciones en neuroticismo. Puntuaciones bajas en el factor $\mathrm{N}$ son indicativas de estabilidad emocional y controlabilidad, mientras que los individuos con puntuaciones elevadas presentan una tendencia al neuroticismo, labilidad emocional y sensibilidad;

\begin{tabular}{|c|c|}
\hline Edad media (DT) & $32.8(15.3)$ \\
\hline Años promedio de duración enfermedad (DT) & $8.1(7.3)$ \\
\hline $\begin{array}{l}\text { Pacientes en: } \\
\text { Fase de actividad (\%) } \\
\text { Intervenidos quirúrgicamente }(\%) \\
\text { Ostomizados (\%) } \\
\text { Con manifestaciones extradigestivas }(\%)\end{array}$ & $\begin{array}{l}55(51.9 \%) \\
41(38.6 \%) \\
19(17.9 \%) \\
25(23.6 \%)\end{array}$ \\
\hline $\begin{array}{l}\text { Tratamiento farmacológico anti-inflamatorio: } \\
\qquad \begin{array}{l}\text { Sin tratamiento } n(\%) \\
\text { Con tratamiento } n(\%) \\
\text { - Aminosalicilatos } \\
\text { - Corticoides } \\
\text { - Inmunosupresores } \\
\text { - Aminosalicilatos + corticoides } \\
\text { - Aminosalicilatos + inmunosupresores } \\
\text { - Corticoides }+ \text { inmunosupresores }\end{array}\end{array}$ & $\begin{array}{r}20(18.8 \%) \\
86(81.1 \%) \\
34(32.1 \%) \\
6(5.7 \%) \\
1(0.9 \%) \\
25(23.6 \%) \\
10(9.4 \%) \\
10(9.4 \%)\end{array}$ \\
\hline
\end{tabular}


manifestando, además, una predisposición al malestar emocional bajo situaciones de estrés. En la presente investigación se ha utilizado la Forma A del EPI.

\section{Procedimiento}

La presente investigación se ha llevado a cabo aprovechando reuniones periódicas, por un lado, de pacientes de la "Asociación de Enfermos de Crohn y Colitis Ulcerosa de la Provincia de A Coruña" y, por otro lado, de la "Asociación de Enfermos de Crohn y Colitis Ulcerosa de Vigo". Los pacientes participaron libremente en el estudio tras su consentimiento informado, cumplimentado los cuestionarios en grupo en una sola sesión. ciones de la enfermedad que hacen referencia a su evolución, más concretamente, actividad clínica, sintomatología extra-intestinal, farmacoterapia, cirugía y ostomías. Los pacientes que se encontraban en una fase de brote puntuaron más alto que los que estaban en un período de inactividad clínica (Figura 1). Para conocer la relación de la actividad clínica con la inestabilidad emocional se controló estadísticamente el efecto de la covariable actividad de la enfermedad (presencia o ausencia de signos y síntomas digestivos como diarreas, dolor abdominal, etc.) mediante un ANCOVA, y se encontró una relación significativa $(\mathrm{F}=10.6 ; p<0.01)$.

Además, se hallaron diferencias estadísticamente significativas entre pacientes con sintomatología extradigestiva y los que no padecían dicha sintomatología $(\mathrm{F}=7.3 ; p<0.01)$, encontrándose valores

Figura 1. Puntuaciones medias en percentiles. Fases de actividad o de remisión clínica

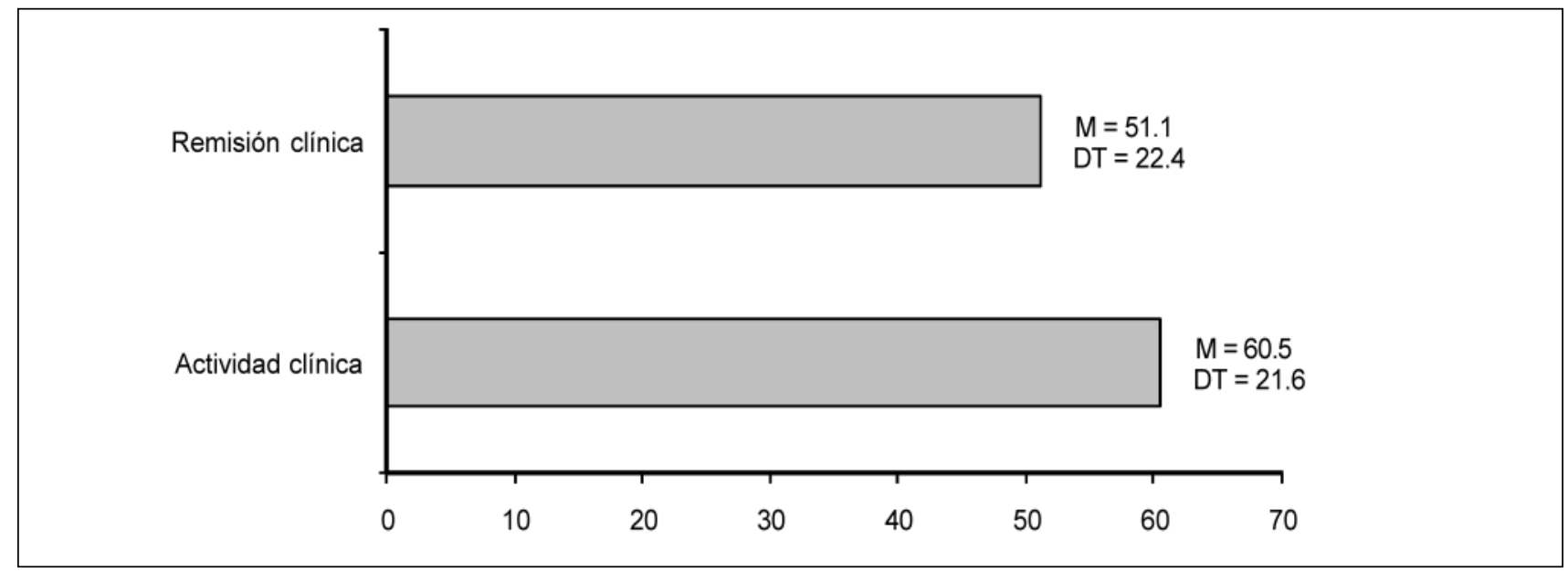

\section{Resultados}

Primeramente, se calculó la puntuación media en neuroticismo y se obtuvo un percentil de 54.4 con una desviación típica de 24.1 para la muestra total. $\mathrm{Al}$ subdividir la muestra en pacientes de $\mathrm{CU}$ y EC se encontró que los EC puntuaron más alto en neuroticismo (55.3) que los de CU (51.2), aunque dichas diferencias no eran estadísticamente significativas. Tampoco se encontraron diferencias significativas entre inestabilidad emocional y las variables sociobiográficas sexo y edad.

Se desarrollaron una serie de tratamientos estadísticos entre la variable psicológica y diversas condi- más altos en neuroticismo para los participantes que presentaban también síntomas extraintestinales como se aprecia en la Figura 2.

Nuevamente se dividió la muestra entre pacientes que estaban sometidos en el momento de realización del estudio a terapia farmacológica y los que no, encontrándose mediante el procedimiento de Spearman una correlación positiva significativa $\left(r_{s}=0.25 ; p<0.05\right)$, siendo los pacientes tratados con fármacos los que en ese momento presentan las medidas mayores (58.4 versus 50.3 ). También se analizó mediante sucesivos ANOVAs bilaterales la relación entre neuroticismo y los principales fármacos empleados para controlar la patología intestinal 
(aminosalicilatos, corticoides e inmunosupresores). En lo que respecta al tratamiento con aminosalicilatos, se apreciaron diferencias significativas entre los enfermos sometidos a dicha terapia farmacológica y los que no $(\mathrm{F}=4.2 ; p<0.05)$; igualmente se encontraron diferencias en los pacientes tratados, entre otros medicamentos, con corticoides $(\mathrm{F}=4.6 ; p<$ $0.05)$; sin embargo, las diferencias no eran significativas en el grupo de pacientes que estaban siendo tratados con inmunosupresores, como único medicamento o en combinación con otros. En la Figura 3 pueden observarse las puntuaciones medias diferenciales en percentiles dependiendo del tipo de tratamiento farmacológico recibido.

Finalmente, no se encontraron diferencias estadísticamente significativas entre pacientes interveni- dos quirúrgicamente y los no operados, ni entre los que habían sido ostomizados y los que no.

\section{Discusión y conclusiones}

Del presente estudio se desprenden varias conclusiones relevantes dentro del ámbito de la investigación psicológica en las EII que reflejan el comportamiento de la variable neuroticismo; variable que se ha visto modificada sustancialmente cuando se ha considerado la muestra de participantes globalmente y cuando se ha subdividido atendiendo a diversos aspectos del curso clínico.

En primer lugar, encontramos que las puntuaciones en inestabilidad emocional están dentro de la

Figura 2. Presencia o ausencia de síntomas extradigestivos

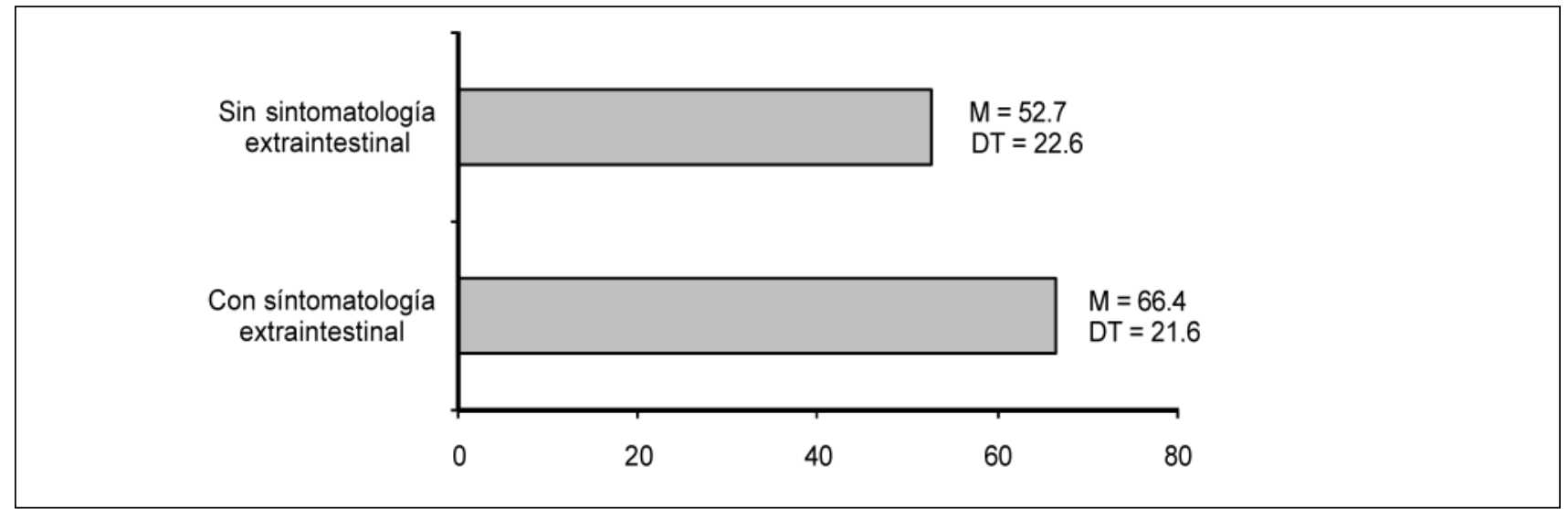

Figura 3. Ausencia o presencia de fármacos

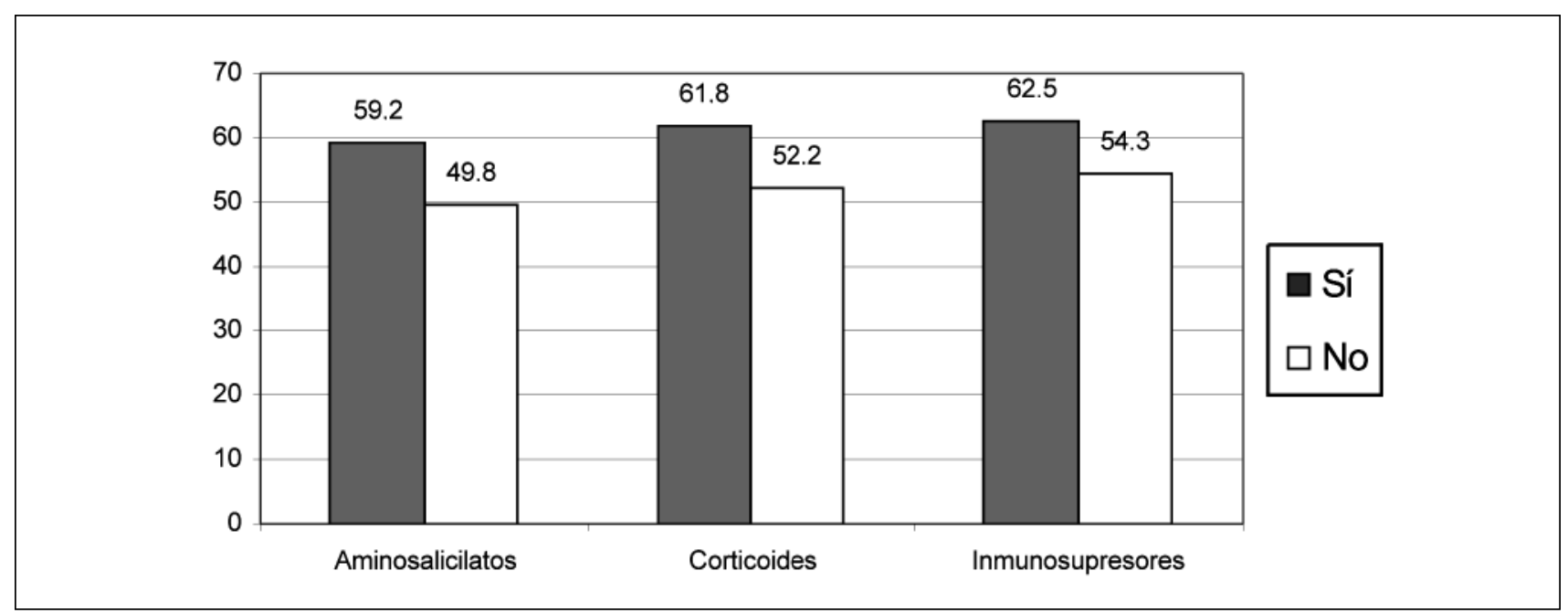


media para todo el grupo de pacientes. Lo mismo se puede decir para las variables subtipo de patología, EC o CU, edad de los pacientes y sexo. Sin embargo, los datos dieron un giro importante cuando se tuvo en consideración el curso clínico de la enfermedad, apreciándose que variaban dependiendo de la presencia-ausencia de actividad clínica, presenciaausencia de sintomatología extradigestiva y de los fármacos utilizados para manejarla.

Observamos que las medidas en neuroticismo se hallaban por encima de la media en los pacientes en fase de actividad clínica de la sintomatología digestiva (diarreas, rectorragias, dolor abdominal, etc.); valores que se incrementaban en los casos de sintomatología extradigestiva (alteraciones cutáneas, osteoarticulares, vasculares, oculares, etc.). En este mismo sentido, los participantes sometidos a tratamiento farmacológico para reducir la inflamación intestinal y manejar los síntomas gastrointestinales o extra-intestinales presentaban valores más altos que aquellos que no estaban sometidos en ese momento a medicación. Además, se verificó que también los resultados diferían dependiendo del tipo de medicación empleada (aminosalicilatos, corticoides o inmunosupresores). De este modo, se encontró que los participantes a los que se les prescribió, exclusivamente o en combinación con otros fármacos, inmunosupresores presentaban los niveles más elevados en neuroticismo, seguidos por aquellos a los cuales sus médicos les habían prescrito corticoides y, en último lugar, por aquellos que recibían aminosalicilatos (derivados del 5-ASA). Finalmente, no se encontraron diferencias en los pacientes intervenidos o no quirúrgicamente, ni siquiera en aquellos que estaban ostomizados.

Aunque los resultados obtenidos en este trabajo no permiten establecer una relación de causalidad entre las variables, podemos hipotetizar una relación bidireccional entre curso clínico y neuroticismo. Por una parte, los pacientes con mayor afectación mostrarían niveles más elevados en neuroticismo. Cabe esperar que los individuos que se encuentran atravesando un período que cursa con síntomas debilitantes y que afectan a su calidad de vida, pueden expe- rimentar modificaciones en determinados aspectos de su personalidad; si bien clásicamente se ha definido la personalidad como un "patrón de rasgos relativamente permanentes y de características singulares que confieren coherencia e individualidad al comportamiento de una persona" (Feist y Feist, 2007, p. 4); sin embargo, también es cierto que las personas atraviesan por situaciones que conllevan importantes cambios en su estilo de vida, como es el caso de una enfermedad física crónica (que supone un importante evento vital estresante), pueden experimentar modificaciones en la conducta. Si dichos cambios son estables en el tiempo y en distintas situaciones, podrían dar lugar a variaciones en determinadas dimensiones de la personalidad (Vinaccia, 2003). Por otra parte, puntuaciones altas en la dimensión de personalidad podrían conducir a la exacerbación de los síntomas una vez que se padece la enfermedad.

En una primera etapa de la investigación de las EII, se tuvo un interés especial en la búsqueda de características específicas de personalidad entre tales pacientes, como agente etiológico debido al desconocimiento de los factores orgánicos que hoy en día se sabe que inciden en la aparición de estas enfermedades. Consideramos que esa línea se abortó prematuramente, y se han presentado resultados generales de dichos pacientes señalando, tal y como cabe esperar, que eran más neuróticos (entre otras variables de personalidad); sin embargo, en futuras líneas de investigación psicológica será importante tener en cuenta la gran heterogeneidad existente en el curso clínico y en la manifestación de las EII, ya que considerar este aspecto permitirá entender la discrepancia en los resultados reflejados en la literatura y que proporcionan tanto evidencia positiva en la asociación de estas variables (p.ej., Barret, Standen, Lee, Hawkey y Logan, 1996), como negativa (p.ej., Garcia y Fernandez, 1998). No tener en cuenta la gran heterogeneidad existente en la evolución clínica de las EII puede dar lugar a sesgos en los resultados de los estudios, dependiendo de la evolución clínica en que se encuentren los participantes en el momento de realizarse la investigación. 


\section{Extended Summary}

Inflammatory bowel diseases (IBD) are chronic diseases that cause inflammation in the digestive tract. Their etiology is unknown and they usually alternate periods of clinical activity with periods of inactivity. IBD includes two conditions, ulcerative colitis (UC) and Crohn's disease (CD). In UC there is diffuse swelling of the lining of the colon, resulting in the most striking symptom, rectal bleeding. For its part, CD involvement can occur in any portion of the digestive tract, with the most common symptoms being diarrhea and abdominal pain (Podolsky, 2002). Its prevalence has increased in recent decades, it can occur at any stage of life and it has a similar distribution in both males and females (Farrokhyar, Swarbrick and Irving, 2001). The causes of these diseases are unknown and treatment is palliative, showing noticeable side effects.

The complexities and complications of these diseases have a major impact on patients' quality of life (Levenstein, 2004; López, Moreno, Devesa \& Rodríguez, 2005). For this reason, researchers have considered the association between inflammatory bowel diseases and psychological disorders, stress and/or personality factors. According to the literature, a greater prevalence of psychological distress has been found among patients for ulcerative colitis and Crohn's disease than in the general population (Guthrie, Jakson, Shaffer, Thompson, Tomenson \& Creed, 2002), especially depression and anxiety. Research shows that stress exacerbates gastrointestinal symptoms (Duffy Zielezny Marshall Weiser, Phillips, Byers et al., 2001) and that coping strategies can influence a better or worse adaptation to inflammatory bowel diseases (Jones, Wessinger \& Crowell, 2006). Finally, it was also confirmed that these patients may have higher scores on various personality factors: neuroticism (Sheffield \& Carney, 1976), introversion (Liedtke, Freyberger \& Zepf, 1977), "locus" of internal control (Steinhausen \& Kies, 1982), obsessive traits (Helzer, Chammas, Norland, Stillings \& Alpers, 1984) alexithymia (Porcelli, Leoci, Guerra, Taylor, \& Bagby, 1996) and trait anxiety (Tocci, Lepre, Liotta, Mason, Costa, Tabotra \& Miccini, 1997), among others.

Neuroticism has been one of the most studied personality dimensions and in this way, it is known that people with high levels of neuroticism tend to have extreme emotional reactions and show greater difficulties in recovering their previous state after going through a stressful situation. Additionally, neuroticism affects psychological well-being (Emmons \& Diener, 1985) and is related to physical illness (Friedman and Booth-Kewley, 1987; Eysenck, 1991).

The literature review conducted by Vidal, Gomez and Peri (2003) showed that neuroticism is one of the most studied personality variables in the field of IBD. They found higher scores than for the general population in the personality variable neuroticism (Gathman, Linzmayer \& Grunberger, 1981), without differences between UC and CD patients (Robertson, Ray, Diammond \& Edwards, 1989; Barret, Standon, Lee and Edwards, 1996). Moreover, high scores in neuroticism are associated in those patients with low levels of quality of life related to health (Moreno, Lopez, Rodriguez and Garrosa, 2007).

UC and CD are diseases which show a highly variable evolution, from the surprisingly benign in some cases to the highly virulent in others (Podolsky, 2002). In some patients there is alternation between periods of activity and remission, while in others periods of activity are almost permanent and lead to a clear deterioration. It is also worth noting that there are very heterogeneous clinical pictures, and we can find patients whose symptoms are strictly digestive, while other patients are affected, besides the gastrointestinal tract, in other organ systems (the skin, eyes, kidneys, etc.). For this reason, the choice of medical treatment varies from patient to patient, depending on factors like the severity of symptoms, type of pathology, the exact phase and their general condition. Also, the response to this treatment is very diverse, proving to be very favorable in some cases while in others its refractoriness becomes apparent, meaning patients require multiple hospitalizations and even different surgeries.

\section{Objectives}

Our study examines the relationship between neuroticism and the clinical course of IBD, and we anticipate finding differences in neuroticism depending on the phase of disease activity-inactivi- 
ty, the presence or absence of extradigestive symptoms and the type of treatment.

\section{Method}

Participants: to conduct the study, a sample of 60 women and 46 men selected through non-random sampling were recruited. The outpatients were diagnosed with IBD according to clinical, radiological, endoscopic and pathological parameters. Of the 106 participants, 49 were suffering from $\mathrm{CU}$ and $57 \mathrm{EC}$.

Instruments: (a) Questionnaire on inflammatory bowel diseases. A protocol was designed to gather information on certain aspects of chronic inflammatory bowel disease. The first section contains the main socio-biographical data, while the following section provides information on the history and evolution of the disease. (b) The Eysenck Personality Inventory (EPI), is a questionnaire developed in 1964 by Eysenck and Eysenck from the Maudsley Personality Inventory, and consists of 57 items on three scales to assess two dimensions of personality, and to detect the scale of social desirability. The two dimensions measured by this instrument are based on an orthogonal pattern, extraversion-introversion (factor E) and emotional stability-emotional instability (neuroticism or factor $\mathrm{N}$ ). In this case, we considered only the scores for neuroticism.

Procedure: this research has been carried out using regular meetings, one the one hand with patients from the "Association of Crohn's disease and Ulcerative Colitis in the province of A Coruña and, secondly, of the Association of Crohn's disease and Ulcerative Colitis of Vigo. Patients participated freely in the study after signing informed consent, and completed some questionnaires as a group in one session.

\section{Results}

First, we calculated the mean score for neuroticism and obtained a percentile of 54.4 with a standard deviation of 24.1 for the total sample. By subdividing the sample in UC and $\mathrm{CD}$ patients, $\mathrm{CD}$ patients were found to score higher on neuroticism (55.3) than UC (51.2), although these differences were not statistically significant. Nor were there significant differences between emotional instability and socio-biographic variables sex and age.

Second, a series of statistical treatments were done between the psychological variable and various disease conditions related to its course (that is, clinical activity, extra-intestinal symptoms, pharmacotherapy, surgery and ostomies). Patients who were in clinical remission showed lower scores on neuroticism $(\mathrm{M}=51.1, \mathrm{SD}=22.4)$ than participants who were undergoing clinical activity $(\mathrm{M}=60.5$, $\mathrm{SD}=21.6)$. To understand the relationship of clinical activity with emotional instability, the effect of the covariate of disease activity (presence or absence of signs and gastrointestinal symptoms such as diarrhea, abdominal pain, etc.) was statistically controlled. An ANCOVA found a significant relationship ( $\mathrm{F}=10.6, p<0.01)$.

In addition, patients with extraintestinal symptoms had a mean neuroticism score of 66.4 (SD = 21.6), whereas patients who did not have such manifestations had a score of 52.7 ( $\mathrm{SD}=22.6$ ). Statistically significant differences arose between patients with extradigestive symptoms and those who had not suffered such symptoms $(\mathrm{F}=7.3, p$ $<0.01$ ), showing higher scores in neuroticism for participants who also had extraintestinal symptoms.

Subsequently, the sample was divided between patients who were undergoing drug therapy at the time of completion of the study and those who were not. Using Spearman's procedure a significant positive correlation was found $\left(r_{s}=0.25, p<0.05\right)$, and the patients treated with drugs at that time have higher measures (58.4 versus 50.3). The average score for neuroticism were higher in all patients treated with drugs than in untreated patients. These were aminosalicylates $(\mathrm{M}=59.2$ "versus" $\mathrm{M}=$ 49.8), steroids ( $M=61.8$ "versus" $M=52.2)$ and immunosuppressive ( $\mathrm{M}=62.5$ "versus" $\mathrm{M}=54.3)$. Using successive bilateral ANOVAs, the relationship between neuroticism and the main drugs used to control intestinal pathology (aminosalicylates, steroids and immunosuppressant) was also analyzed. With respect to treatment with aminosalicylates, significant differences were found between patients on the drug therapy and those not receiving such treatment $(\mathrm{F}=4.2, p<0.05)$; differences were 
also found in patients treated with steroids, in addition to other drugs $(\mathrm{F}=4.6, p<0.05)$; however, the differences were not significant in the group of patients being treated with immunosuppressants (a single drug or in combination with others).

Finally, we found no statistically significant difference between patients operated on and those not operated on, nor among those having an ostomy and those not.

\section{Discussion and conclusions:}

This study points to some relevant conclusions within the scope of psychological research into IBD that allows us to improve our understanding of the evolution of the neuroticism variable; a variable that varied substantially when the entire sample of participants was taken into account and when the sample was subdivided based on aspects of clinical course. First, we found that scores on emotional instability are within the average for the whole group of patients. The same is true for the subtype of pathology variables, CD or UC, age and gender. However, when consideration was given to the clinical course of illness, neuroticism values varied depending on the presence or absence of clinical activity, presence or absence of extradigestive symptoms and the drugs used to manage intestinal disorders.

Although the results obtained in this research did not allow us to proclaim a causal relationship between variables, we can hypothesize a bidirectional relationship between clinical course and neuroticism. On the one hand, patients with greater involvement show higher levels in neuroticism. It is expected that individuals who are going through a period with debilitating symptoms that affect their quality of life, could have certain aspects of their personality modified. Although classically personality is defined as a "pattern of relatively permanent traits and unique characteristics that give coherence and individuality to a person's behaviour" (Feist and Feist, 2007, p. 4,) people who go through situations that involve significant changes, as is the case of a chronic physical illness (a stressful life event) may also experience changes in behaviour that, if they are stable over time and in different situations, could lead to variations in certain dimensions of personality (Vinaccia, 2003). Moreover, high scores on the personality dimension could lead to the exacerbation of symptoms once they have the disease. In the first stage of the investigation of IBD, there was particular interest in finding specific personality characteristics among such patients, such as the etiologic agent, rather than organic factors that today are known to influence the occurrence of these diseases.

We would argue that this line was aborted prematurely, and there have been overall results of these patients indicating, as expected, they were more neurotic (among other personality variables). In future research, however, it will be important to take into account the great heterogeneity in the clinical course and manifestation of IBD, because considering this aspect will let us understand the difference in results reported in the literature and provide both positive evidence on the association of these variables (Barrett, Standen, Lee, Hawkey and Logan, 1996), and negative (Garcia and Fernandez, 1998). Not taking into account the great heterogeneity in the clinical course of IBD can lead to bias in the results of the studies, depending on the clinical course in which they are participants at the time of the investigation.

\section{Referencias}

Barret, S.M., Standen, P.J., Hawkey, C.J. y Logan, R.F. (1996). Personality, smoking and inflammatory bowel disease. European Journal of Gastroenterology \& Hepatology, 8, 651-655.

Duffy, L.C., Zielezny, M. A., Marshall, J. R., Weiser, M. M., Phillips, J. F., Byers, T. E., Ogra, P. L. y Saxon, G. (2001). Comparison of stress indices in gauging clinical activity in patients with inflammatory bowel disease. Journal o Traumatic Stress, 5, 601-613.

Emmons, R.A. y Diener, E. (1985). Personality correlates of subjective well-being. Personality Social Psychological Bulletin, 2, 89-97.

Eysenck, H.J. (1991). Personality as a risk factor in coronary heart disease. European Journal of Personality, 5, 81-92. 
Eysenck, H.J. y Eysenck, B.G. (1964). Eysenck Personality Inventory. London: Odre and Stoughton.

Farrokhyar, F., Swarbrick, E. e Irvine, E. (2001). A critical review of epidemiological studies in inflammatory bowel disease. Scandinavian Journal of Gastroentorology, 36, 2-15.

Feist, J. y Feist, G.J. (2007). Teorías de personalidad ( $6^{a}$ edic.). Madrid: McGrawHill/Interamericana de España.

Fletcher, R.H., Fletcher S.W. y Wagner E.H (1989). Epidemiología clínica. Barcelona: Ediciones Consulta.

Friedman, H.S. y Booth-Kewley, S. (1987). The "disease-profne personality": a meta-analytic view of the construct. Americam Journal, 42, 529-455.

García, E. y Fernández-Rodríguez, C. (1998). Algunos Factores predictores en la enfermedad de Crohn. Psicothema, 10, 143-151.

Gathmann, P. Linzmayer, L. y Grungerger, J. (1981). Contribution to he objective evaluation of the personality features of the colitis patient. Wiener Medizinische Wochenschrift, 131, 421.425.

Guthrie, E.; Jackson, J.; Shaffer, J., Thompson, D.; Tomenson, B. y Creed, F. (2002). Psychological disorder and severity of inflammatory bowel disease predict health-related quality of life in ulcerative colitis and Crohn's disease. Americam Journal of Gastroenterology, 8, 1994-1999.

Helzer, J.E., Chammas, S., Norland, C.C., Stillings, W.A. y Alpers, D.M. (1984). A study of the association between Crohn's disease and psychiatric illness. Gastroenterology, 86, 324-330.

Jones, M.; Wessinger, S. y Crowell, M. (2006). Coping Strategies and interpersonal support in patients with irritable bowel syndrome and inflammatory bowel disease. Gastroenterolgy and hepatology, 4, 474-481.

Levenstein, S. (2004). Embracing complexity: what determines quality of life in inflammatory bowel disease? European Journal of Gastroenterology \& Hepatology, 16, 1253-1255.

Liedtke, R., Freyberger, H. y Zepf, S. (1977). Personality features of patients with ulcerative colitis. Psychotherapy and Psychosomatic, 28, 187-192.

López, B.; Moreno, B.; Devesa, J. M. y Rodríguez, A. (2005). Relación entre variables sociodemográficas y clínicas y calidad de vida relacionada con la salud en pacientes con enfermedad inflamatoria intestinal. Revista Española de Enfermedades Digestivas, 97, 887-898.

Moreno, B.; López, B .; , Rodríguez, A. y Garrosa, E. (2007). The influence of personality factors on health-related quality of life of patients with inflammatory bowel disease. Journal of Psychosomatic Research, 62, 39-46.

Podolsky, D (2002). Inflammatory bowel disease. New England Journal Medical, 347, 417-429.

Porcelli, P., Leoci, C., Guerra, V., Taylor, G. y Bagby, R. (1996). A longitudinal study of alexithymia and psychological distress in inflammatory bowel disease. Journal of Psychosomatic Research, 41, 569-573.

Robertson, D.A., Ray, J., Diamond, I. y Edwards, J.G. (1989). Personalitiy profile and affective state of patients with inflammatory bowel disease. Gut, 30, 623-626.

Sheffield, B.F. y Carney, M.W. (1976). Crohn's disease: a psychosomatic illness? British Journal of Psychiatry, 128, 446-450.

Steinhausen, H y Kies, H. (1982). Comparative studies of ulcerative colitis and Crohn's disease in children and adolescents. Journal Children Psychology and Psychiatry, 23, 33-42.

Tocci, A., Lepre, L., Liotta, G., Mazzoni, G., Costa, G., Tabotra, L., y Miccini, M. (1997). Familial and psychological risk factors of ulcerative colitis. Italian Journal of Gastroenterology and Hepatology, 29, 395-398.

Vidal, A.H.; Gómez, E.G. y Peri, .M. (2003). Aspectos psicológicos y psiquiátricos en las enfermedades inflamatorias intestinales. Revista de Psiquiatría de la Facultad de Medicina de Barcelona, 30, 97-104.

Vinaccia, S. (2003). El patrón de conducta tipo C en pacientes con enfermedades crónicas. Revista Colombiana de Psiquiatría, 13, 161-168.

Artículo recibido: 06/11/2009

Revisión recibida: 11/01/2010

Aceptado: 15/02/2010 